Özet:

Bizans döneminde "Metopan" olarak adlandırılan, Osmanlılar döneminde ise Tophane adını alan semtte top döküm tesis-

leri inșasının Fatih Sultan Mehmed

tarafından başlatıldığı bilinmektedir.11. Bayezıd döneminde genişletilen top döküm tesisleri, Kanuni döneminde yıktırılmış ve yeniden, ancak bu kez daha büyük olarak inșa edilmiștir. III. Selim döneminde başlatılan yenileme hareketleri orduda da yansımasını bulmuș ve bu dönemde

Tophane semtinde top döküm tesislerine ilave olarak Nizam-1 Cedid askerlerine ait

Topçu ve Top Arabacıları Kışlaları inşa edilmiştir. Bu yapılar topluluğundan günümüze sadece iki adet top döküm binas kalmıştır. Günümüzde mevcut iki top döküm binasından büyük olanı XVIII Yüzyıl'ın ortalarına, küçük top döküm binası ise XV. Yüzyıl'a tarihlenebilir.

Yapılardaki koruma amaçlı onarım çalışmaları, 1958-1959 yılları arasında birinci dönem ve 1973-1984 yılları arasında ise ikinci dönem olmak üzere incelenebilir. "Top Döküm Binaları" 1992 yılında Mimar

Sinan Üniversitesi'ne devredilmiștir.

Summary:

Guns had proved to be very effective in the conquest of Constantinople by the Ottoman

Turks in $1453 \mathrm{AD}$. This is the reason why Sultan Mehmed the Second, also named briefly "Fatih" (The Conqueror) had built these gunfoundries directly after the conquest of the city,

out of the Genoese city walls in front of the

Galata Gate. The first foundry had to be extended at the end of the $X V$. Century during the reign of Sultan Bayezid the Second. Only

20 years after this extension, in the time of Sultan Süleyman the First, known as

"Süleyman the Magnificient", the foundries could not meet the requirements of the Empire any longer. Only two foundry buildings remained from the whole complex to our days.

The large building with a row of five dome and two aisles covered with barrel-vaults is dated back to the XVIII. Century. The domes rest on arches and pendentives supported by eight columns. The smaller building having a square plan had been built by the "Conqueror", in the middle of the XV.

Century. It has a single dome as a roof, again with a lantern at its apex. The restoration of the existing buildings took place in 1958-1959 and in the years from 1973 to 1984. The build-

ings were used as "Gun Museum" until they were left to Mimar Sinan University in 1992.

The rearrangement of the interior was carried out by the specialists of the University. Since 1998 the buildings are in use as "Cultural And Exhibition Center of Mimar Sinan University". Anahtar Kelimeler:

Top döküm tesisleri, Tophane, Tophane-i Amire, Restorasyon Keywords:

Foundry, Gun-Foundries, Tophane, Restoration

\title{
Top Döküm Binaları (Tophane-i Amire) ve Onarimlari*
}

Doç. Dr. Oğuz Ceylan MSÜ Mimarlık Fakültesi, Restorasyon Ana Bilim Dalı

* Bu makale, yazar tarafindan 18-20 Şubat 1998 tarihleri arasında İstanbul'da düzenlenen "ICOMOS Türkiye-Yunanistan 2. Ortak Toplantısı, Prof. Dr. Cevat Erder Onuruna Uluslararası Seminer"de bildiri olarak sunulmuş ve tasarım+kuram Dergisi için yeniden gözden geçirilerek yayına hazırlanmıştır

Bizans döneminde "Metopon" olarak adlandırılan (Janin 1950, 427) Osmanlılar döneminde ise Tophane adını alan semtte, top döküm tesisleri inşaasının Fatih Sultan Mehmed tarafından başlatıldığı bilinmektedir (Kömürcüyan 1952, 259). İstanbul'un fethinde topların gücünün görülmesi bu tür tesislerin yapımında etken olmuş olabilir. Fatih döneminde (1451-1481) bir top imalathanesi ve topçular kışlası inşası ile başlayan yapılaşma daha sonraki dönemlerde de artarak devam etmiştir. Fatih döneminden itibaren Galata surlarının bu bölgede yeralan kapısı "Tophane Kapısı" olarak anılmıştır (Harita 1).

\section{Bayezıd (1481-1512) döneminde} genişletilen top döküm tesisleri, Kanuni (1520-1560) döneminde yıktırılmış ve yeniden, ancak bu kez daha büyük olarak

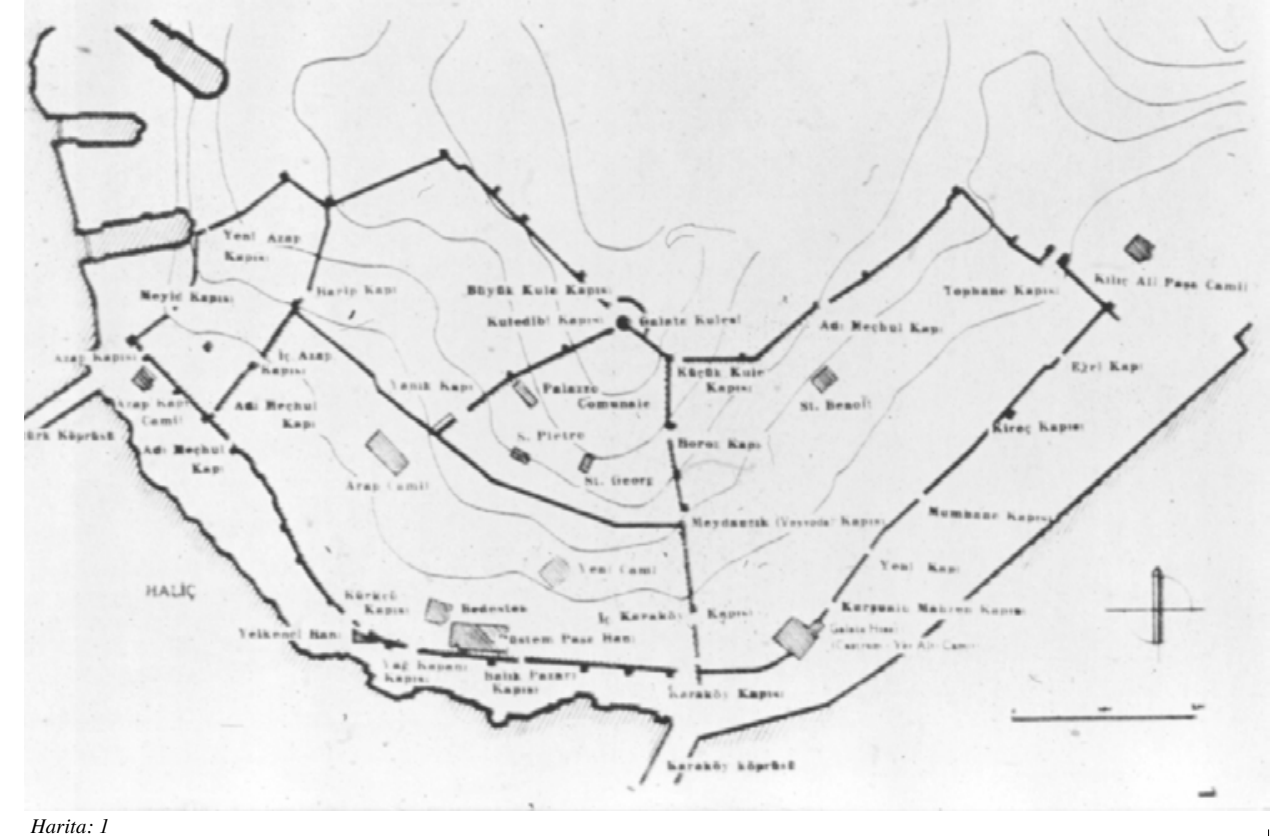


inşa edilmiştir (Kömürcüyan 1952, 259). Değişik işlevlere sahip yapıların inşaası zaman içerisinde artarak devam etmiştir. Örnek olmak üzere 1723 senesinde Tophane-i Amire'nin ve civarın su ihtiyacının karşılanması amacıyla, ayrıca yangın tehlikesine karşı bir su sarnıcı inşa edilmesi gösterilebilir (Cezar 1963, 351).

III. Selim döneminde (1789-1807) başlatılan yenileşme hareketleri orduda da yansımasını bulmuş ve bu dönemde Tophane semtinde top döküm tesislerine ilâve olarak Nizam-ı Cedid askerlerine ait Topçu ve Top Arabacıları Kışlaları inşa edilmiştir (Incicyan 1956, 95) (Raif 1988, 13). Bu döneme ait ve Tophane semtindeki yapılaşmayı gösteren çok sayıda görsel malzeme mevcuttur (Resim 1) (Arslan 1992, 194). III. Selim dönemini yansitan ve Tophane semtinin denizden görünüşünü gösteren gravürlerde sahil kesiminde kışlalar ve geride 5 kubbesi ve çatı fenerleri ile dikkat çeken büyük top döküm binası ile birlikte, tek kubbeli ve çatı fenerli küçük top döküm binası görülmektedir. İncicyan, kışlalar ile birlikte top dökümünün yanısıra havan topu dökümünün de yapıldığını belirttiği beş kubbeli, kâgir bir yapıdan bahsetmektedir (inciciyan 1956, 95). H. Ayvansarayi ise sahilde bu kışlaların yanısıra bir de tek minareli bir caminin inşa edildiğini belirtmektedir

(Ayvansarayi 1281, 58).

1 Mart 1823 yılındaki Firuzağa yangınında top döküm binasının bir kısmı ile birlikte Topçu ve Top Arabacıları kışlaları ve cami yanar (Cezar 1963, 369). Bunun üzerine II. Mahmud döneminde (1808-1839) yeniden girişilen imar hareketlerinde bu yapıların sslahı ile birlikte Nusretiye Camii ve top dökümü ile ilgili bir de demirhane inşa edildiği görülür (Ayvansarayi, 1281, 58) (1).
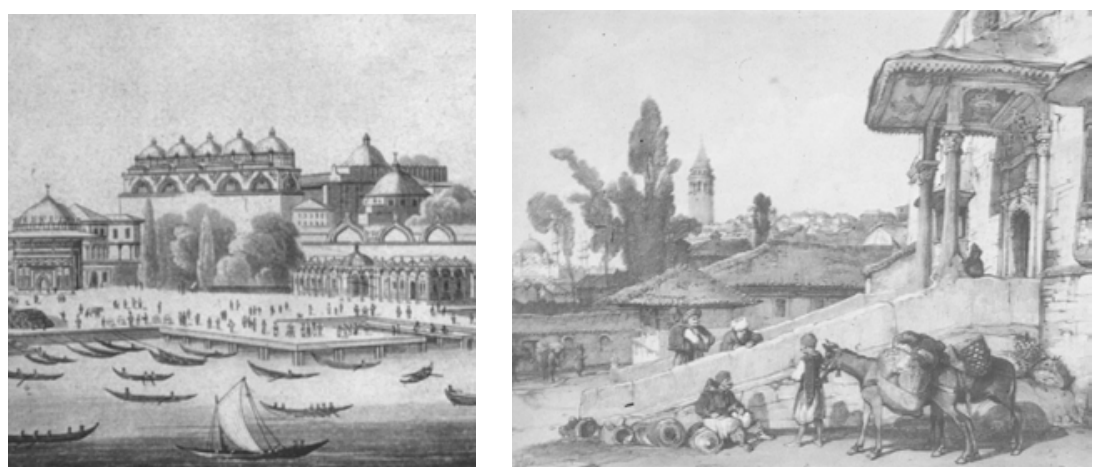

1864 yangınından sonra inşæe dilen ve

Nusretiye Camii'nin karşı sırasında yeralan Müşirlik Dairesi ve Sanayi Kışlası yapıları, 1958 yılındaki yol genişletme çalışmaları sırasında ortadan kaldırılır (Ünsal 1969, 48) (Resim 2).

II. Mahmud dönemini yansitan Lewis'in resimlerinden Tophane yapıları ve sahil kışlaları hakkında detaylı bilgi edinilebilmektedir. Lewis'in büyük top döküm binasının güney cephesini gösteren resminde, cümle kapısının her iki yanında yeralan taş konsollar ve bu taş konsolların taşıdığı ahşap cumbalar ile birlikte barok tarzda inşa edilmiş saçak ve bu saçağa doğru yükselen taş rampa görülebilmektedir (Resim 3). Fatih döneminde top döküm tesislerinin

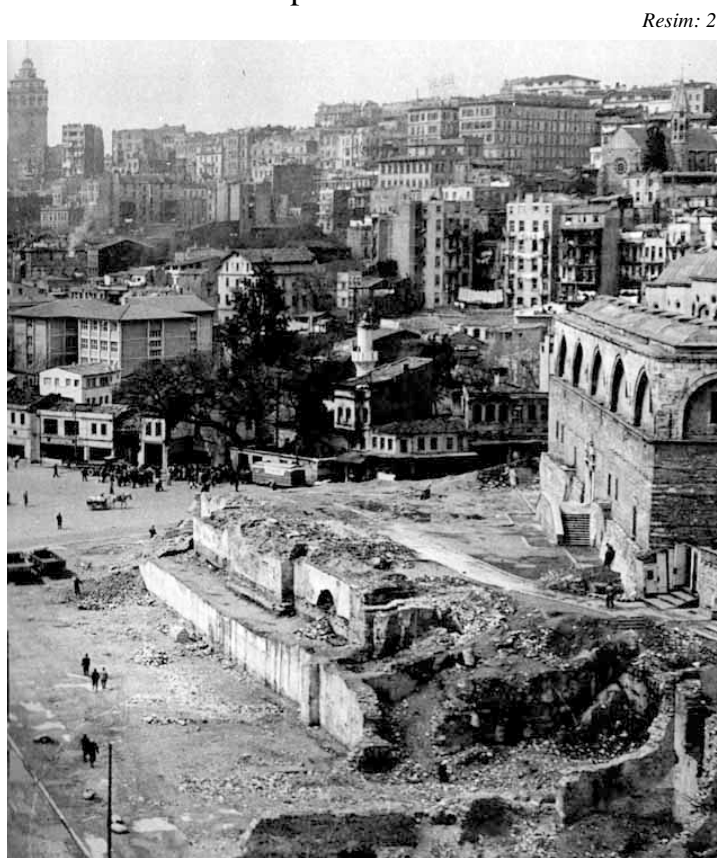

Resim: 3

Harita: I Galata Surlari'nı ve Tophane kapısını gösteren harita (Eyice, 1969: 85) Resim: 1 Tophane semtini ve top döküm binalarını gösteren bir gravür. (Hobhouse, 1812: 831) Resim: 2 1956 yılındaki yol genişletme calışmaları ve top döküm binaları. (şahenk, 1996: 60) Resim: 3 Büyük top döküm binasinın cümle kapısını, giriş saçağını ve rampayı gösteren resim. (Lewis, 1837: 6-7) 


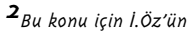

18.09.1986 tarihli Istanbul

Rölöve ve Anitlar

Müdürlüğü'ne sunulan

raporuna bakılabilir.

(Istanbul I Numaralı Kültür

ve Tabiat Varlıklarin

Koruma Kurulu, Tophane-i

Amire dosyasi)

${ }^{3}$ C.Can, Sultan

Abdülmecid'in inşa ettirdiği

ilk kagir saray olan bu

kasrin mimarinin Smith

olduğunu ancak yapının

daha f̧ok bir Fossati

tasarımı olduğu hissini

verdiğini belirtmektedir.

Can C. (1993) Istanbul'da

XIX.Yüzyıl Batılı ve

Levanten Mimarlarin

Yapilari ve Koruma

Sorunlari, (yayinlanmamis

doktora tezi), YTÜ Fen

Bilimleri Ens.,

Istanbul. 185

4 yapı günümüzde

Mimar Sinan Üniversite-

sinin kullanımindadir ve

misafirhane olarak

ișleulendirilmiștir. inşaası için Tophane semtinin seçilme nedenleri şu şekilde sıralanabilir :

Konum: Tophane semti Haliç'in giriş

kısmında ve Topkapı Sarayı'nın karşısında yeralmaktadır. Böylece savunma ve kontrol işlevleri yerine getirilebilmektedir.

Ayrıca semtin deniz ile olan bağlantısı ve buna bağlı olarak, dökülen top ve güllelerin gemilere kolaylıkla yüklenmesi önemli bir husus olarak karşımıza çıkmaktadır.

${ }_{1}$ Teknoloji: Top ve güllelerin dökümü için gerekli hammaddenin tesislere getirilmesi, top ve güllelerin dökümü ve kullanılacakları yerlere nakledilmeleri belirli bir arazi kesitinin oluşumunu gerekli kılmaktadır. Üretimi yapılan objelerin ağırlığının önem kazandığ $\breve{1}$ bu tür teknolojilerde, tesislerin kurulduğu arazinin eğimi ön plana çıkmaktadır. Tophane semtinde de bu oluşum gerçekleşmiş, top döküm tesisleri üst kotta yeralmıştır.

Tophane semti ve top döküm tesisleri ile birlikte diğer askerî yapılar, zaman içerisinde uygulanmış bir tasarım projesinin parçaları olarak yorumlanmalıdırlar. Yer seçiminden itibaren başlayan bu tasarım süreci zaman içerisinde olgunlaşmış ve diğer yapılarıyla birlikte askerî ve sanayi işlevli bir semtin doğmasına yol açmıştır (Wiener 1998, 119).

R. Mantran bu oluşuma şu şekilde dikkat çekmektedir :

“Dökümhanenin etrafında çok kalabalık bir mahalle gelişmiştir ve Pera'ya çıkan yokuşlar kadar deniz kenarı da evler, camiler, pazarlar ve hamamlarla bezenmiştir (Mantran 1986, 81) .... Tophaneler binlerce insan çalıştıran çok büyük imalathanelerdir. Faaliyetinin gereği olarak çeşitli üretim kesimlerini barındırmakta ve çok çeşitli malzemeler kullanmaktadırlar. Demir, bronz, odun, muşamba, bez, zift, katran vbg... (Mantran 1986, 4). Tophane'deki dökümcüler ve topçular dökümhanenin içinde inşa edilmiş olan kışlalarda ikamet etmektedirler. Top kundağı imalatçıları, mermilerin çıktı̆̆ı alev ağızları için kalıp yapanlar, dökümcüler; bunların herbirinin ayrı bir mahallesi bulunmaktadir"(Mantran 1986, 5).

Günümüzde Bursa, Selânik gibi bazı şehirlerde, Tophane olarak anılan bölgeler mevcuttur. İ. Öz, bu bölgelerin Tophane adı ile anılmalarının çeşitli nedenlere dayandığını belirtmektedir. Bu nedenler, eritilmiş maden kullanılarak top dökümünün yapıldığı veya dövme demir tekniğinin kulanıldığ 1 ve top imalinin yapıldığı bir yapının mevcudiyeti, veya kente hakim bir noktada topların konduğu bir bölgenin varlığıdır (2). İstanbul'un Tophane semtinde bulunan askerî yapılardan günümüze sadece, yamaçta yer alan iki top döküm binası ile yapımı 1851 yılına tarihlenen ve Tophane Kasrı (3) olarak bilinen yapı kalmıştır (4).

Tophane yapılar topluluğu, Osmanlı silah sanayinin üretim merkezi olarak önemini Türkiye Cumhuriyeti'nin kuruluş yıllarına kadar devam ettirmiştir. Ankara şehrinin başkent oluşu ile birlikte silah sanayi de başkentte kurulmaya başlanmıştır. Bu yıllarda Zeytinburnu Silah Fabrikası'nda dökülen topların işlenmek üzere Tophane' ye getirildiği bilinmektedir (Çoruhlu 1996, 31). Giderek önemini kaybeden Tophane'deki top döküm yapıları uzun yıllar boş kalmış, 1958 yılında Tophane yapılarının ve çevresinin "Askerî Müze" olarak düzenlenmesi gündeme gelmiştir (Eralp vd. 1983, 7).

Onarım çalışmalarına başlanılan yapıların onarım maliyetlerinin giderek artması karşısında, Millî Savunma Bakanlığı 1992 yılında Tophane yapılarını Mimar Sinan Üniversitesi’ne devretmiştir.

Mimarî ve İşlev 
Tophane semtinde bulunan top döküm yapılarının mimarî özelliklerinin anlaşılabilmesi ancak işlevlerinin doğru tanımlanabilmesi ile olanaklıdır. Evliya Çelebi (Evliya Çelebi 1975, 302-307) ve Kritovulos'da (Kritovulos 1967, 62) top döküm kalıplarının hazırlanması, top dökümünün gerçekleştirilmesi ve döküm sırasında kullanılan malzemeler detaylı olarak anlatılmaktadır. Yazılı anlatımlar ve yerinde yapılan araştırmalar sonucu elde edilen bulgular 1şığında top dökümünün şu şekilde gerçekleştirildiği anlaşılmaktadır:

Top dökümünde kullanılacak hammadde büyük top döküm binasının kuzey cephesinde bulunan iki adet tonozlu geçitten içeri aktarılırdı. Yapının içinde ve alt kotta bulunan işçiler dışarıdan aktarılan hammaddeyi kubbeli ve çevresi ateşe dayanıklı taşlarla örülmüş olan ocaklara iletirlerdi. Bu ocaklarda ergiyen hammadde kanallar vasıtasıyla büyük top döküm binasının güney cephesinde bulunan iki adet çukurda yer alan ve düşey olarak yerleştirilmiş kalıplara yönlendirilirdi. Bu kalıplarda soğumaları için belirli bir süre bekletilen toplar gerekli işlemlerin tamamlanmasından sonra güney cephede yeralan tonozlu geçitlerden geçirilir ve ahşap kızaklar üzerinde kaydırılarak sahile indirilirdi (5).

Günümüzde büyük top döküm binasının içinde iki adet büyük ebatta fırın görülmektedir. Bu nedenle hammadde girişleri, fırın sistemleri ve çıkışlar iki sistemi içerecek şekilde tasarlanmış ve çözümlenmiştir (6). Hammaddenin ergitilmesi için oluşan yükssek 1sı nedeniyle ve açığa çıkan zararlı gazların dışarı atılabilmesi amacıyla üst örtü sisteminde bazı önlemlerin alınacağı doğaldır. $\mathrm{Bu}$ itibarla iç mekan olabildiğince yüksek
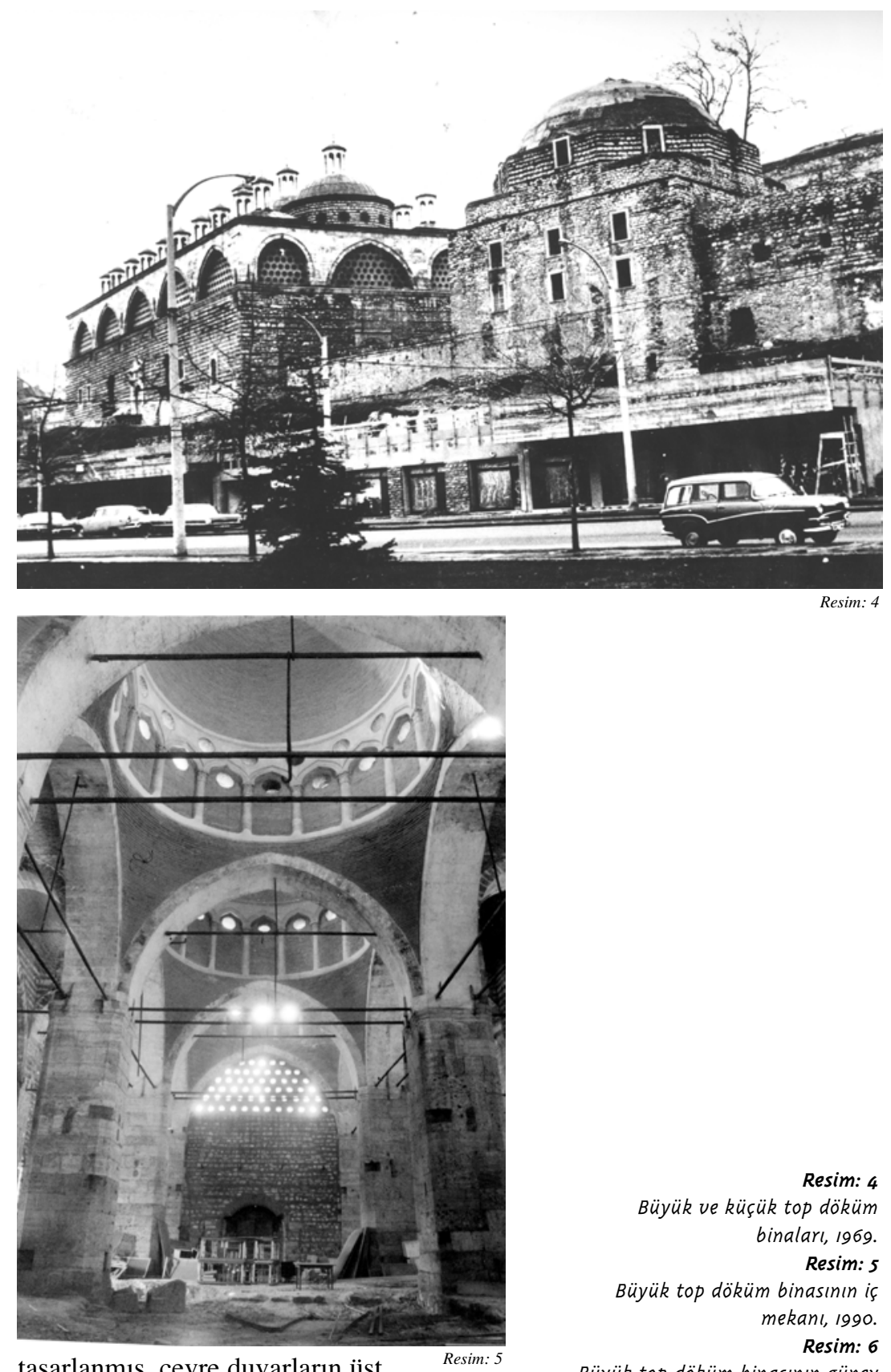

tasarlanmış, çevre duvarların üst

Resim: 5 kotlarında yeralan kemerlerin aynalarında boşluklar oluşturulmuş ve zararlı gazların dışarı atılması için fenerler inşa edilmiştir.

\section{Büyük Döküm Binası:}

Günümüzde mevcut iki döküm binasından batı yönünde yeralanı XVIII. Yüzyıl' in ortalarına tarihlenebilir $(7)$.

Üst örtü sistemini ortada beş kubbe ve her
Resim: 4 Büyük ve küçük top döküm binaları, 1969.

Resim: 5 Büyük top döküm binasinın if mekanı, 1990. Resim: 6 Büyük top döküm binasının güney cephesinde yer alan barok cümle kapisı, 1990.

Resim: 7

Büyük top döküm binasının güney cephesinde yer alan taş konsollar ve tonozlu gefit, 1990.

Resim: 8

Büyük top döküm binasının kuzey cephesinde yer alan ve hammadde girişinin sağlandığı tonozlu geçit ve pencereler, 1990. 


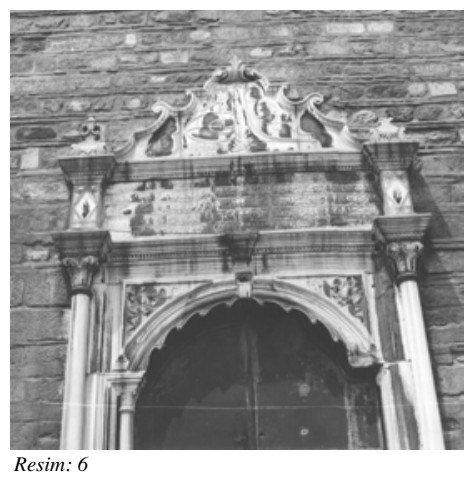

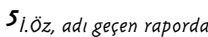
yapmış olduğu yüzey arastirmaları sonucunda toplarin üzerinde

kaydırıldığı sert ağaç malzemenin izlerine rastladığını belirtmektedir.

$\boldsymbol{\sigma}_{\text {Mimar Sinan Universitesi }}$ nce günümüzde yürütülen yüzey arasstirmalar sonucunda, iç mekânin doğu cephesinde ocak olabileceği düš̈unülen bazı kalintilar tespit edilmistir. Bu ocakların küçük obje dökümleri (tabanca, kills vb.) için kulanıldı ı̆ı varsayilmaktadir.

$\mathbf{7}_{\text {l.öz, adı geçen raporda, }}$ sözkonusu yapinin daha eski dönemlere de ait olabileceğini, ancak genel karakteri ile I. Mahmud dönemine ait olabileceğini belirmektedir. Bu görüşü destekleyen bir diğer bulgu, cümle kapisinin üzerinde yeralan kitabeden ebced hesabı ile çikarilan

1790 - 1791 tarihidir. Bu tarihi veren dize şöledir: "Ne muhkem oldu Tophane edüb sultan Selim Abad", bu dizeden Tophane binasinin III. Selim deurinde tamir edildiği anlaşılmaktadır. (Cezar, 1996: 32)

$\boldsymbol{8}_{\text {Genelkurmay Harp Tarihi }}$ Daire Baskkanlı̆ı̆ Askerî Müze Müdürlǚ̆ü' nün Eski Eserler ve Anitlar Müdürlǚ̆ü'ne yazmıs olduğu 13.06.1968 tarih ve $6101-1-68$ saylli yazl.

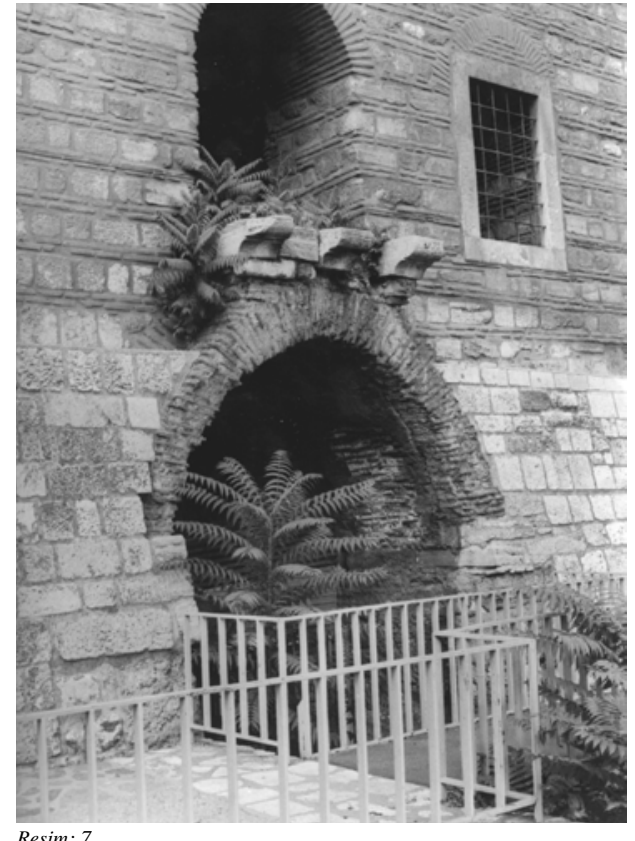

Resim: 7

iki yanda beşer tonozun oluşturduğu büyük döküm binasının iç mekânında üst örtü sistemini taşıyan ve kesme taştan oluşturulmuş sekiz adet ayak mevcuttur. İç mekanda biriken sıcak ve zararlı havanın dışarı atımını sağlamak amacıyla kubbe-lerde birer, tonozlarda ise ikişer adet olmak üzere taş fenerler inşa edilmiştir. Ayrıca kubbe kasnaklarında açılan yuvarlak boşluklar ile havalandırma güçlendirilmiştir. Kubbe kasnaklarının iç yüzlerinde yer alan kabartma sütun ve kemerler dizisi görsel zenginlik sağlamaktadır. Kubbeden kemerlere geçiş pandantiflerle sağlanmıştır. Kemerlerde yer alan gergi demirlerinin çift olarak kullanıldı $\breve{g}$ dikkat çekmektedir. İç mekân, işlev gereği tek mekân olarak çözümlenmiştir. Zemin kat döşeme kotuna yönelik yüzey araştırmaları yapılmış ancak net bir bilgi elde edilememiş̧ir. Çeşitli kullanımlar sonucunda muhdes döşemelerin inşa edilmek istendiği bilinmektedir(8).

Cephelerde zemin kat döşeme kotuna kadar kesme taş olan duvar dokusu, bu kottan sonra iki sıra tuğla ve bir sıra taştan

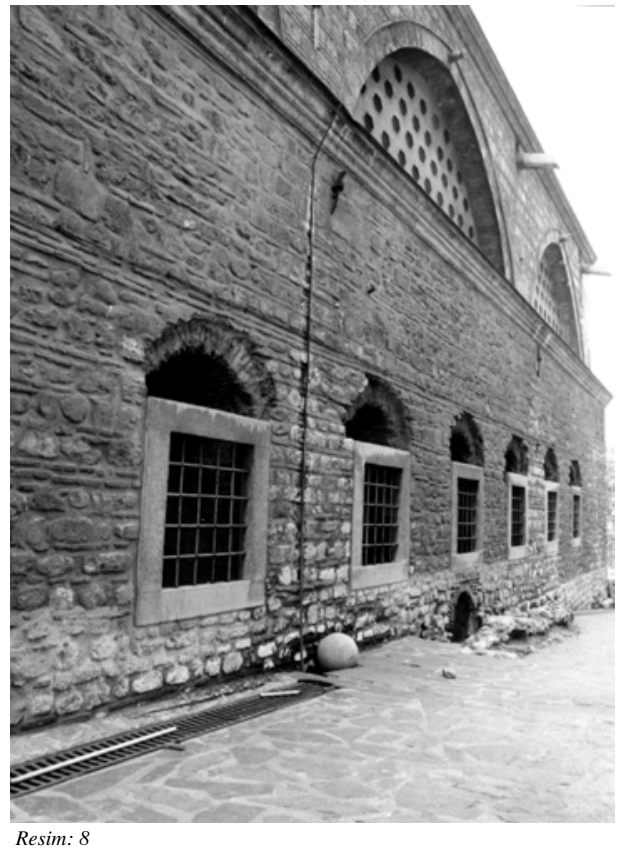

oluşan duvar dokusuna dönüşmektedir.

$\mathrm{Bu}$ doku bir taş profil ile üst kotta yer alan kemerler dizgesinden ayrılmaktadır. Uzun kenarında beş, kısa kenarında ise üç kemerin bulunduğu kesme taştan inşa edilmiş kemer dizgesinin aynaları günümüzde altıgen boşluklardan oluşmaktadır.

Büyük döküm binasının güney cephesinde, dökülen topların binadan dışarı çıkarıldığı tonozlu geçitlerin üstlerinde yeralan taş konsollar dikkat çekmektedir. Lewis'in resminde bu taş konsolların üzerindeki ahşap cumbalar görülebilmektedir (Bkz. Onarılar Bölümü ).

\section{${ }_{1}$ Küçük Döküm Binası}

Günümüzde mevcut iki döküm binasından doğu yönünde yer alanı XV. Yüzyıl'ın ortalarına tarihlenebilir. Üst örtü sistemini tek bir kubbenin oluşturduğu ve kare plana sahip binada zararlı gazların atımını sağlayan bir fener dikkat çekmektedir. Sıralı moloz taş kullanılarak oluşturulan cephe duvarları kubbe kasnağında taş-tuğla tekniği kullanılarak oluşturulmuş 

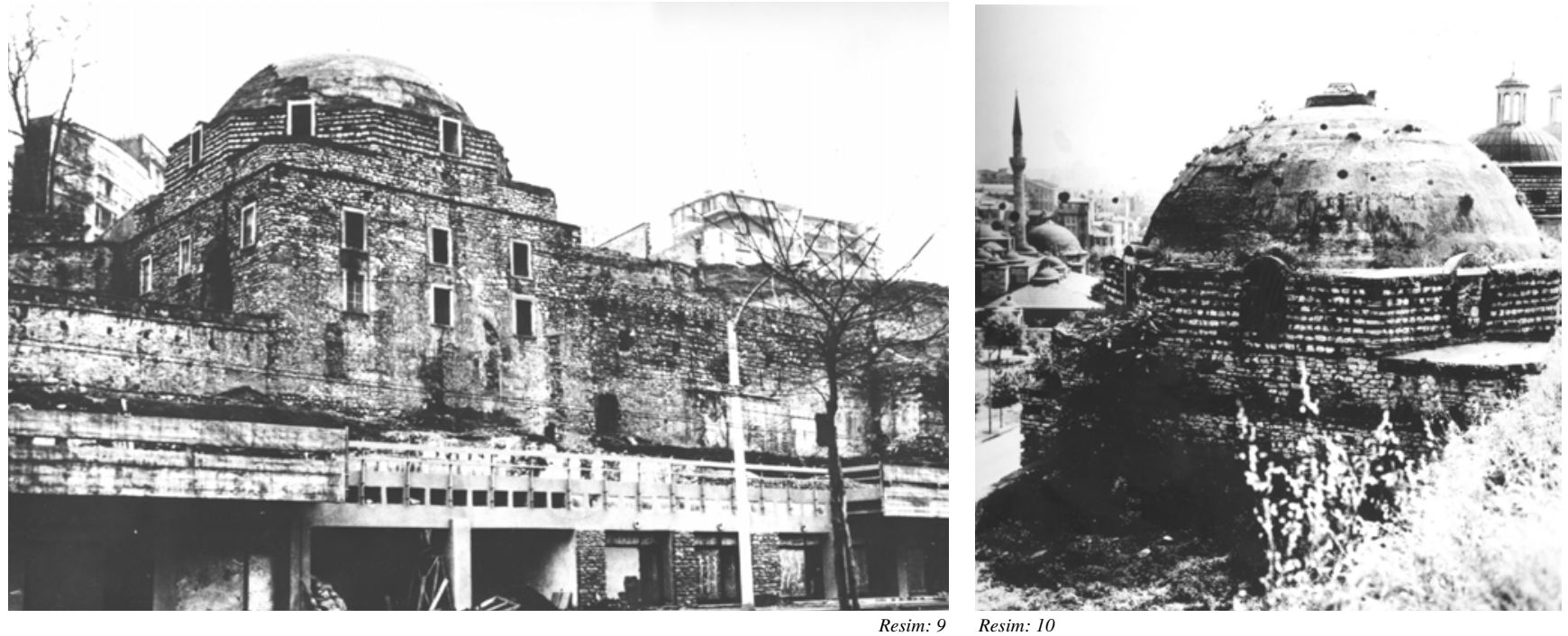

duvar örgüsüne dönüşmektedir (Bkz.Onartmlar Bölümü ).

Bina iç mekânında büyük bir döküm çukuru bulunmaktadır. Büyük döküm binasında olduğu gibi bu binada da döküm çukuru tonozlu bir geçit ile dış mekâna açılmaktadır. Bu binada diğer binada görülen ocak sistemleri ve zararlı gazların dışarı atımını sağlayan kemerler dizgesi içinde yeralan boşluklar bulunmamaktadır. Sövesiz ve tuğla kemerli pencereler dikkat çekmektedir.

Küçük döküm binasının doğu duvarına bitişik konumda yeralan ve 1972 yılındaki sondaj çalışmaları sırasında ortaya çıkarılan dört gözlü su sarnıcının çeşitli dönemlerde, yapılar topluluğunun su ihtiyacının giderilmesine yönelik kullanıldığı varsayılmaktadır.

Su sarnıcının daha sonraki dönemlerde inşa edildiği, küçük döküm binasının sarnıca bitişik cephesinde yeralan penceresinin kapatılmasından anlaşılmaktadır.

\section{${ }_{1}$ Çevre Oluşumu}

Günümüzde alt yol kotunda yeralan bir dükkan dizisi dikkat çekmektedir. Bu dükkanlar İstanbul Belediyesi tarafından 1958 yılındaki yol genişletme çalışmaları sırasında yol ile top döküm binalarının oturduğu plato arasındaki kot farkı nedeni ile oluşan cephenin değerlendirilmesi amacı ile inşa edilmiştir (9). 1972 yılı onarımları sırasında çevre düzenlemesi kapsamında günümüzde görülen teraslamalar gerçekleştirilmiş ve
Resim: 9 Büyük top döküm binasının cümle kapısını, giriş saçă̆ını ve rampayı gösteren resim.

Resim: 10 Küçük top döküm binasının doğu cephesi ve kubbe, 1969.

Resim: II 1990 yılında top döküm binaları.

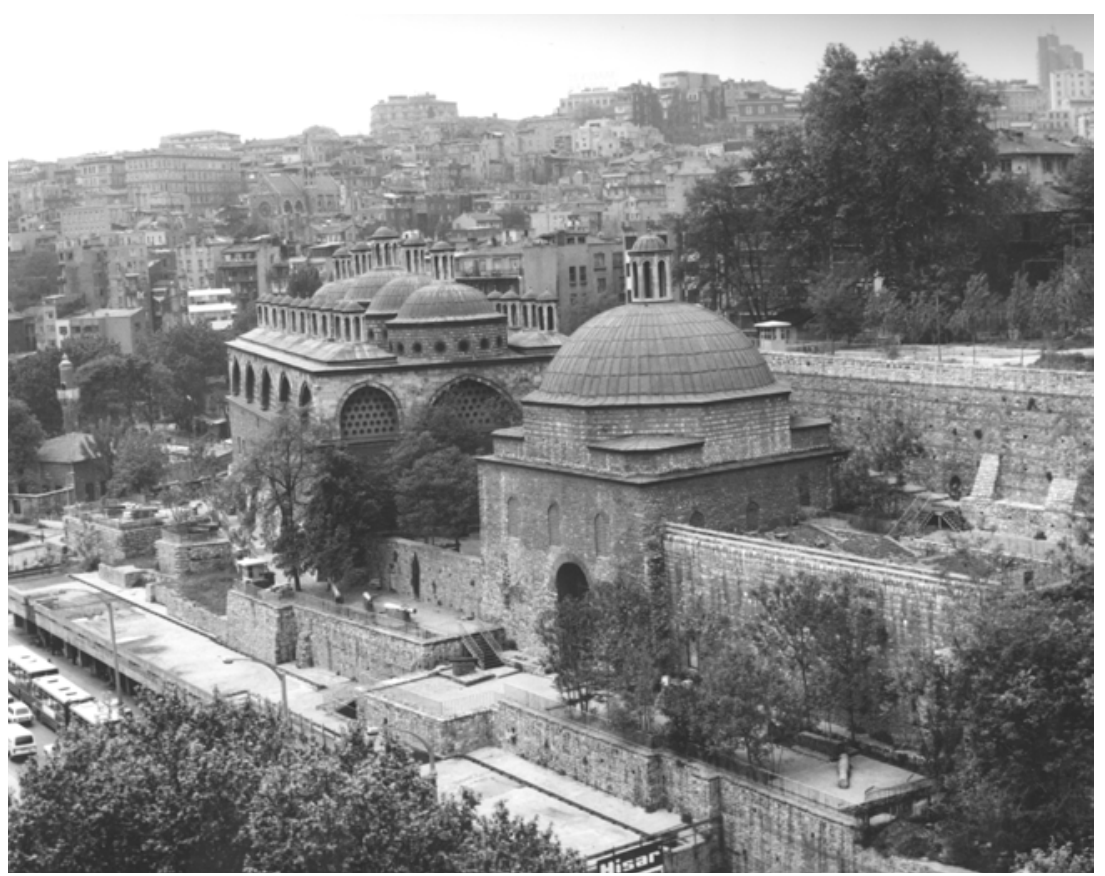


9 Istanbul Belediyesi ile Gayrimenkul Eski Eserler ve Anitlar Yüksek Kurulu arasındaki yazışmalardan, dükkanların inşaasının

30.09.1959 tarih ve 1225 sayll kurul kararı ile uygun görüldüğü ancak inşaatın 1965 senesinde devam

etmekte olduğu dönemin

basınından ögrenilmektedir.

(11.01.1965 tarihli son

Havadis gazetesi).

$10_{\text {Bu dönem de yapilan }}$ imalatlar hakkındaki detaylı bilgi, Rölöve ve Anitlar Müdürlüğ̈̈'nün "Tophane-i Amire"

dosyasındaki ataşman defterleri'nde mevcuttur.

IIstanbul I Numaralı Kültür ve Tabiat Varlıklarını Koruma Kurulu ve Anitlar Müdürlüs̆̈̈’nün ilgili dosyaları.
Sekil: I

Birinci dönem onarımlarını gösteren fizimler. (1958-1959) Zemin kat planı.

\section{Şekil: 2}

Birinci dönem onarımlarını gösteren fizimler. (1958-1959) Boy kesit. parselin kuzey bölümüne bir idare binası inşa edilmiştir. Ayrıca topların sergilenmesi amacıyla çok sayıda taş kaideler oluşturulmuştur(10).

\section{Onarımlar}

İlgili kurumların arşivlerinde (II) yapılan araştırma ve incelemeler sonucunda günümüzde mevcut döküm binalarının koruma amaçlı onarım çalışmalarının iki farklı dönemde gerçekleştirildiği belirlenmiştir. Bu dönemler; "Birinci Dönem Onarımları (1958-1959 Yılları)”, ile “İkinci Dönem Onarımları (1973-1984 Yılları)" olmak üzere incelenecektir.

\section{Birinci Dönem Onarımları}

\section{(1958-1959 Yillart):}

Top döküm binaları ile ilgili koruma amaçlı onarım çalışmalarının başlangıcı, İstanbul Belediye Reisliği’nin “Top Dökümhanesi Tesislerinin Restorasyonuna ve Civarının Tertip ve Tanzimine Ait Rapor" başlıklı bir rapor ile birlikte hazırlanan “Tophane Binası Rölövesi'nin 11. 04. 1958 tarihinde Gayrimenkul Eski Eserler ve Anttlar Yüksek Kurulu'na iletilmesi olarak kabul edilebilir.

$\mathrm{Bu}$ raporda konular, top dökümhane tesislerinin etrafının tertip ve tanzimi ve bu tesislerin restorasyonu olarak iki grup halinde ele alınmıştır. Rapora ek olarak sunulan projeler de bu çerçeve içerisinde
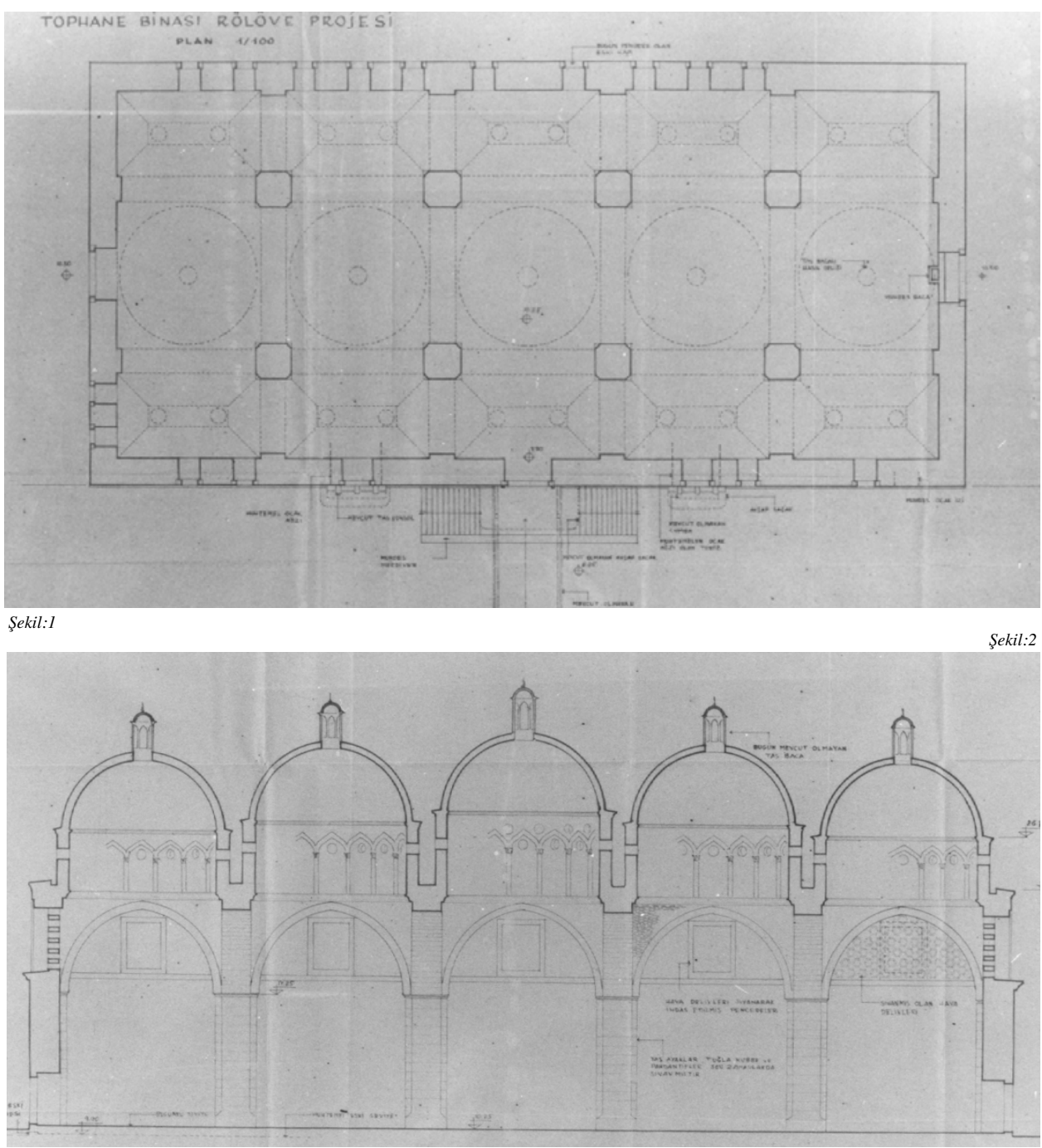
hazırlanmıştır. Bu raporun önemi top döküm binalarının ilk onarım öncesi durumlarının açıklanmış olmasıdır. Söz konusu raporda daha sonraki onarımlara 1şı tutabilecek bazı önemli bulgular ve projede öngörülen hususlar şu şekilde sıralanabilir:

\section{BB̈̈yük Döküm Binast:}

-Büyük top döküm binasının cümle kapısının önünde yeralan merdiven ve sahanlığın yıkılması, buna karşılık Lewis'in tablosunda görülen rampanın yeniden inşaası öngörülmüş,

-Lewis'in tablosunda görülen ve cümle kapısının önünde yeralan ahşap saçağın varlı̆̆ını belgeleyen, izleri taş duvar üzerinde görülen oyukların mevcudiyeti tespit edilmiş ancak ahşap saçağın yeniden inşaasına gerek görülmeyerek projede yer verilmemiş,

-Lewis'in tablosunda görülen ve cümle kapısının her iki yanında yeralan iki adet ahşap cumbaya ait tahribat izleri taş duvarda tesbit edilmiş, ancak ahşap saçakta yapılan yorum cumbalar için de geçerli kılınmış,

-Beden duvarlarındaki mevcut pencerelerin muhdes olduğuna değinilmiş ancak tarihî bir dönemi temsil ettiklerinden dolayı gerekli tamiratın yapılarak olduğu gibi bırakılması uygun görülmüş,

-Döküm sırasında oluşan gazların atımını sağlayan kemer dizgesi içinde yeralan altıgen boşlukların kapatıldığ muhdes pencerelerin konduğu tespit edilmiş, bu durumun düzeltilmesi gerektiği belirtilmiş, -Kubbelerin muhdes olduğu, ancak bir devri temsil ettiklerinden muhafaza edilmeleri gerektiği, ancak kubbelerin üzerinde yeralan ve mevcudiyetleri vesikalarla saptanan taş bacaların esas karakteri oluşturmaları açısından yeniden

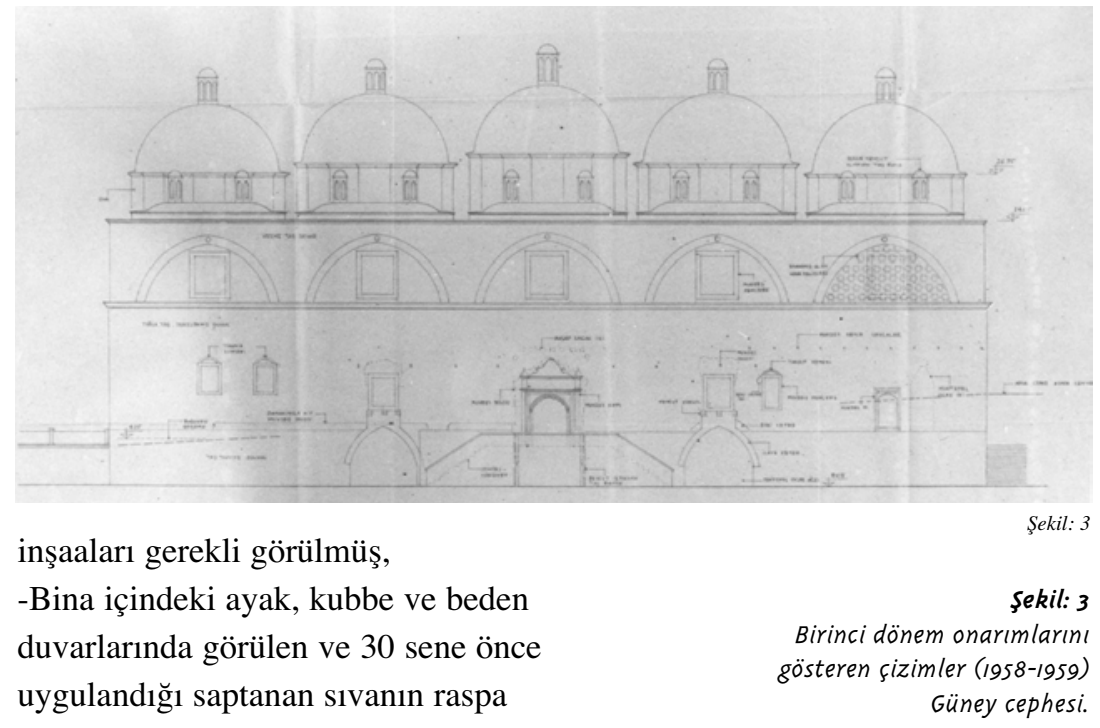

edilmesi ve esas bünyenin ortaya çıkarılması gerektiği belirtilmiş, -Mevcut döşemenin yeni olduğu, bu döşemenin kaldırılarak esas döşemeye ulaşılmasının gerekliliği vurgulanmış ayrıca mevcut asma katın da kaldırılması gerektiği vurgulanmıştır.

\section{Küçük Döküm Binası :}

-Bina içindeki mevcut ahşap muhdes katların kaldırılması gerektiği, -Sıvaların raspa edilerek esas bünyenin ortaya çıkarılması gerektiği,

-Beden duvarları üzerinde yeralan muhdes pencerelerin muhafaza edilmesi,

-Kubbenin üzerinde bulunduğu çeşitli vesikalarla tespit edilen taş bacanın yeniden inşaası öngörülmüş ve projeler bu bulgu ve görüşler çerçevesinde hazırlanmıştır.

İstanbul Belediye Reisliği tarafından hazırlanarak Gayri Menkul Eski Eserler ve Anitlar Yüksek Kurulu'na sunulan söz konusu rapor ve projeler hakkında kurul, geç dönemlerdeki onarımlara esas oluşturacak olan "17. 05.1958 tarih ve 906 say1lı karar"' alır ve bu kararda, gerek büyük gerek küçük döküm binalarına yönelik tekliflerin genelde uygun bulunduğu ancak cümle kapısı üzerindeki ahşap saçak, 


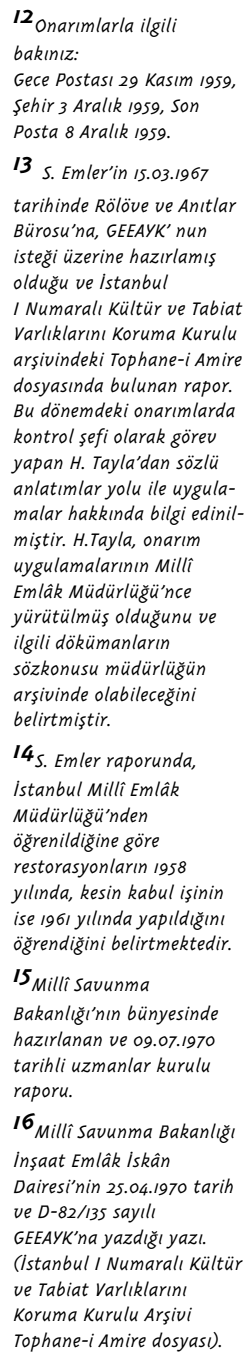

cephedeki mevcut konsollara oturan ahşap cumbalar, çatı suyunun alınması, zemin döşemesi, iç sıvalar ve beden duvarlarındaki pencereler gibi konularda geniş etüdlerin yapılmasının gerekliliği vurgulanarak diğer maddelerin uygulanabileceği belirtilir.

"Birinci Dönem Onarımları" olarak nitelendirilen bu dönem onarım uygulamaları basında da yansımalarını bulmuştur. 1958 yılında onarımların devam ettiği, 1959 yılında ise onarımların tamamlandığ günün basınından öğrenilebilmektedir(12). $\mathrm{Bu}$ dönemdeki onarım uygulamalarının kapsam ve niteliği S. Emler tarafından hazırlanan ve bu dönem onarım projesini esas alan bir rapordan öğrenilebilmektedir (13). Bu raporda;

-Cümle kapısının önünde yeralan merdivenin yıktırıldığı ancak rampanın yapılmadı $\breve{g}$,

-Ahşap saçağa ait taş duvardaki izlerin horasan derz yapımı sırasında yok edildiği,

-Lewis'in tablosunda görülen ve taş konsollara oturan ahşap cumbaların gerisinde yeralan ve rölövede gösterilmiş olan dolgu taş duvarın yerinde görülemediği,

-Döküm esnasında oluşan zararlı gazların atımını sağlayan ve kemer dizgesi içinde yeralan peteklerin önüne yapılan muhdes pencerelerin kaldırılmış ve havalandırmanın temin edilmiş olduğu, -Kubbelerin üzerinde yeralması gerektiği belirtilen ve projede önerilen taş bacaların inşa edilmiş olduğu,

-Ayak ve beden duvarlarındaki sıvaların raspa edilmiş olduğu ancak kubbe ve pandantiflerdeki sıva katmanlarının mevcut olduğu,

-Her iki binada görülen ahşap ve muhdes asma kat ve katların kaldırılmış olduğu, -Küçük döküm binasında ise herhangi bir inşaî faaliyetin görülmediği belirtilmektedir ${ }^{(14)}$. Millî Savunma Bakanlığı bünyesinde hazırlanan bir raporda ise büyük top döküm binasının üst örtü sisteminin onarımı ile güney ve batı cephelerinin onarımının 1958-1959 yıllarında gerçekleştirildiği bildirilmektedir(15).

\section{IIkinci Dönem Onarımları (1973-1984 Yullart)}

“İkinci Dönem Onarımları"nın başlangıcı Millî Savunma Bakanlığı İnşaat ve Emlâkİskân Dairesi'nin bünyelerinde program ve proje tanzimi için bir heyet kurularak ve bu heyetin mahallinde gerekli çalışmayı yapıp, Gayri Menkul Eski Eserler ve Anttlar Yüksek Kurulu'na bildirmesi olarak kabul edilebilir( ${ }^{(16)}$. Bu raporda, daha önce sadece büyük döküm binasında onarım yapıldığı, güney cep-hesindeki tonozlu geçitlerin yarı yarıya toprağa gömülü olduğu, özellikle küçük döküm binasının bir an evvel onarıma alınması gibi konulara yer verildiği görülmektedir.

Millî Savunma Bakanlığı' nın bünyesinde kurulan bir kurul 09. 07. 1970 ve 10. 09. 1970 tarihli, mevcut durumu saptamaya ve o döneme kadar geçen süre içindeki onarımları tespit etmeye yönelik bir rapor ile birlikte restitüsyon ve restorasyon projelerini hazırlar. $\mathrm{Bu}$ projeler doğrultusunda ve Millî Savunma Bakanlığı ile Kültür ve Turizm Bakanlığı arasında yapılan bir protokol sonucu onarım çalışmalarına başlanır.

İ. Öz, 29. 05. 1974 tarihli ve 732-478 sayılı ara raporunda, çalışmaların sürdürüldüğünü, büyük binada kısa olan çörtenlerin uzatılması, iki adet izabe ocağının içlerinin açılarak koruma altına alınmalarının sağlanması, küfeki taklidi 


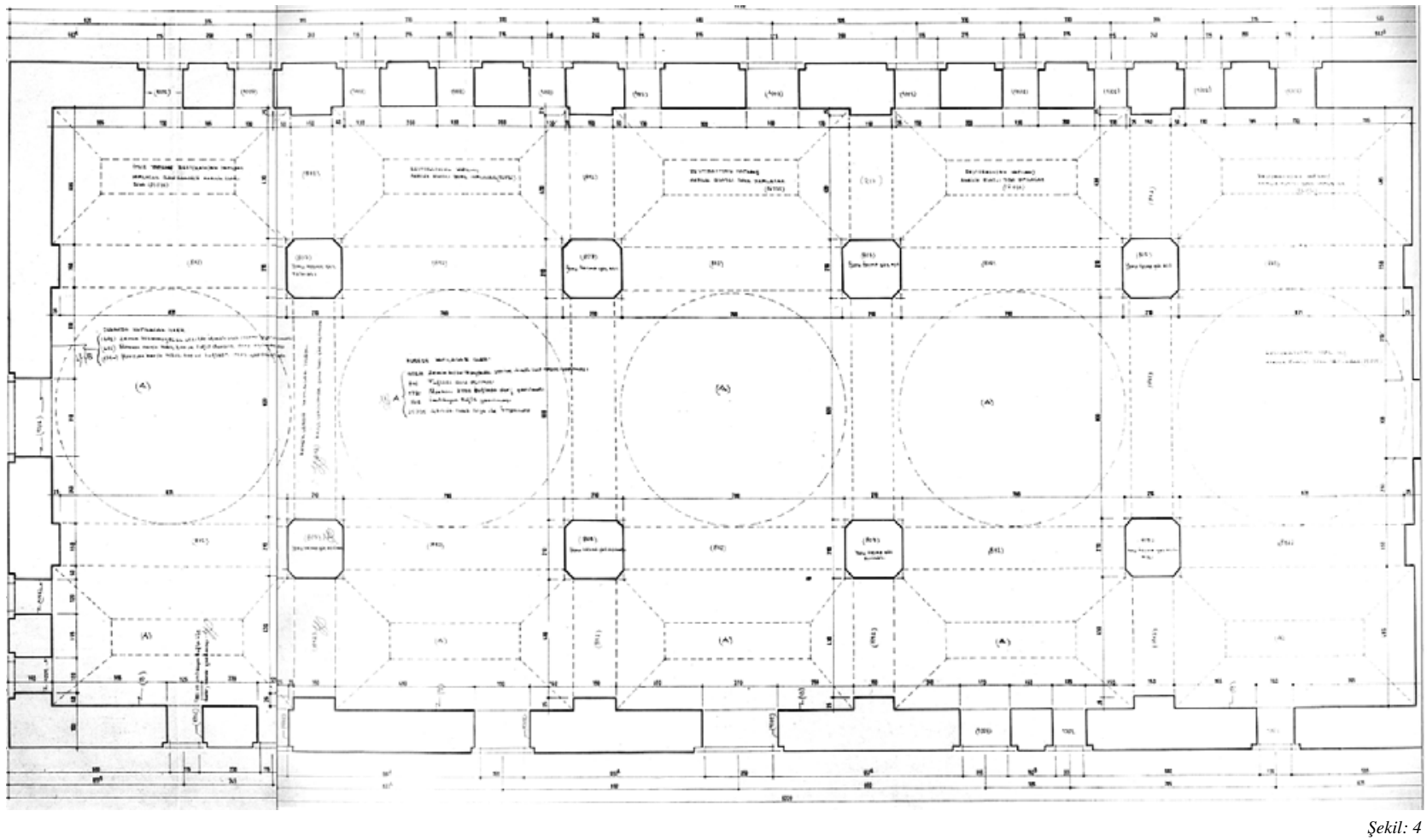

döşeme yapılması, küçük binada ise kasnakta pencere olmayan projenin uygulanması ve çevre düzeninin projeye uygun hale getirilmesi gerektiğini belirtir.

“İkinci Dönem Onarımları”nın 1984 yılına kadar sürdüğü İ. Öz' ün 18. 09. 1986 tarihinde İstanbul Rölöve ve Anıtlar Teknik Müdürlüğü’ne vermiş olduğu rapordan öğrenilmektedir. $\mathrm{Bu}$ raporda küçük döküm binasının tamamen restore edildiği, bahçede topların kronolojik sergilemelerinin başlamış olduğu, büyük döküm binasının dış onarımlarının tamamlanarak iç onarımlara başlandığı ancak 1985 yılından itibaren ödenek tahsis edilememesi

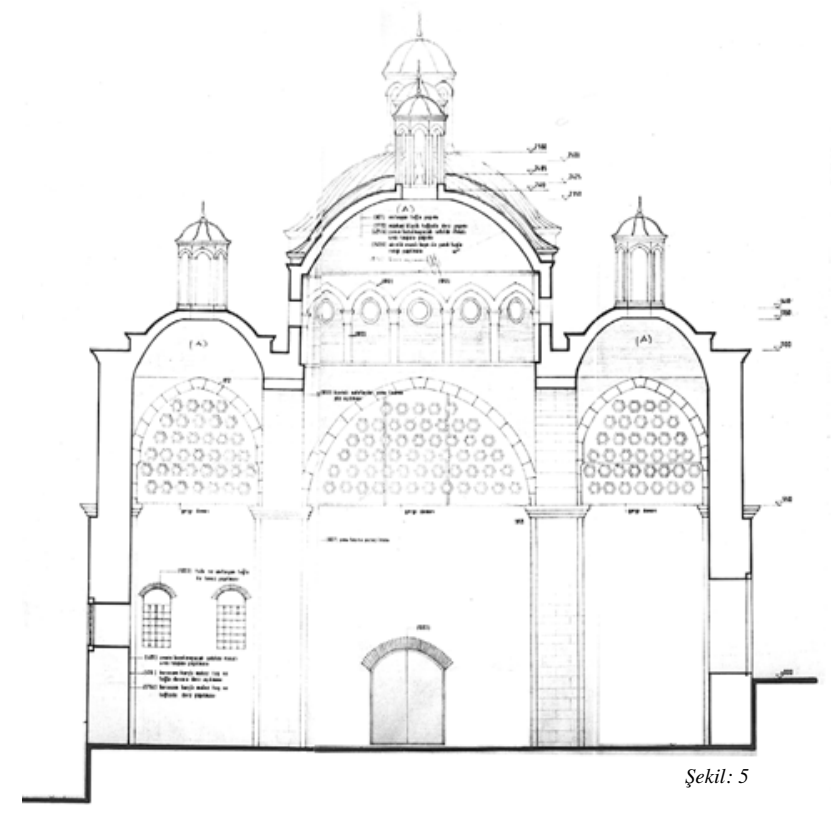
nedeniyle onarımların durduğu, özel mimarisi ile tek örnek olduğu vurgulanan bu yapıda bakımsızlığa bağlı olarak onarımları yapılan kısımların bile tekrar harap duruma geldiği belirtilmektedir.

\section{Değerlendirme}

Tophane semtinde yeralan “Top Döküm Binaları"nın koruma amaçlı onarım uygulamalarının iki dönemde gerçekleştirildiği, 1958-1959 yıllarını kapsayan birinci döneminde ağırlıklı olarak büyük döküm 
Şekil: 4

Ikinci dönem onarımlarını gösteren f̧izimler. (1973-1984). Büyük top döküm binası, Zemin kat planı.

şekil: 5

Ikinci dönem onarımlarını gösteren f̧izimler. (1973-1984). Büyük top döküm binası, en kesit.

\section{şekil: 6}

ikinci dönem onarımlarını gösteren f̧izimler (1973-1984). Büyük top döküm binası, Güney cephesi.

Şekil: 7

ikinci dönem onarımlarını gösteren f̧izimler (1973-1984). Kü̧ük top döküm binası, Zemin kat planı.

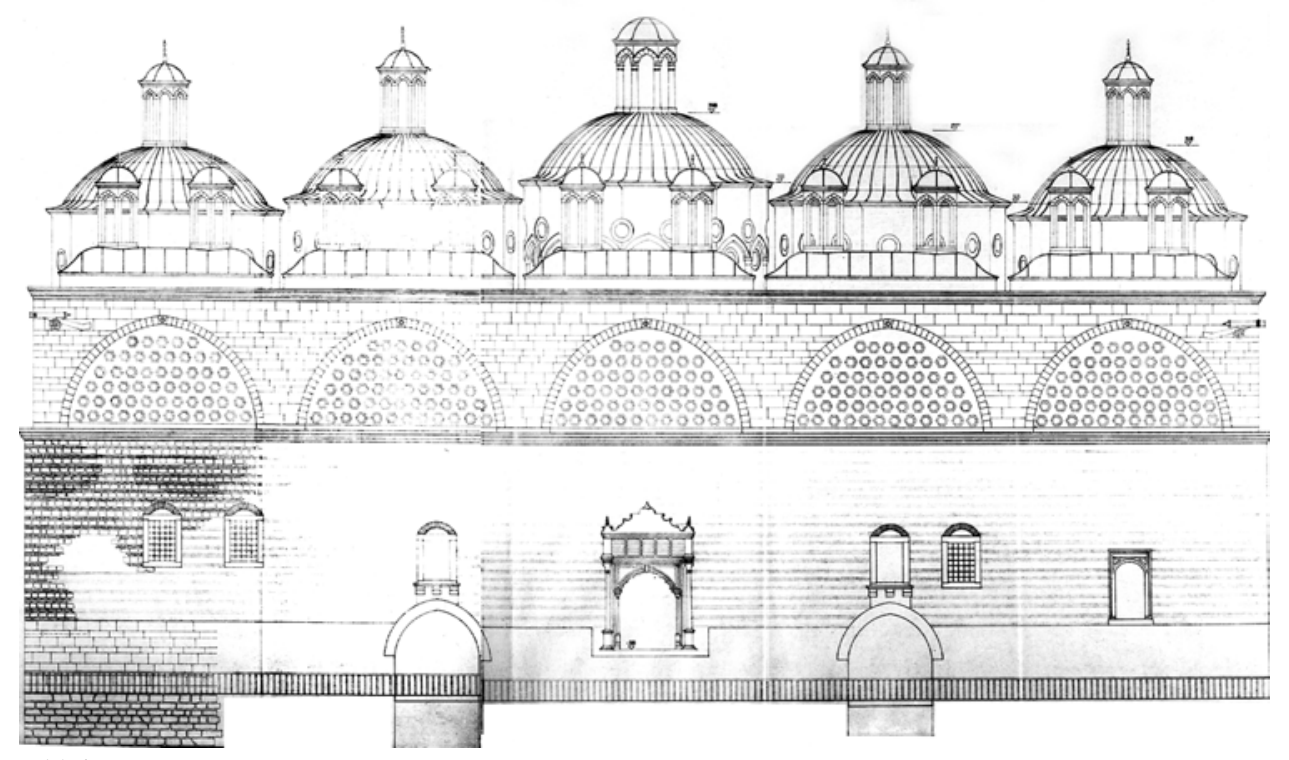

Şekil: 6

binasının ele alındığı buna karşılık

1973-1984 yıllarını kapsayan ikinci döneminde ise ağırlıklı olarak küçük döküm binası ile çevre düzenleme çalışmalarının yürütüldüğü anlaşılmaktadır.

Birinci dönemdeki onarım çalışmalarında büyük döküm binasının üst örtü çalışmaları kapsamında, varlıkları görsel belgelerle saptanan kagir havalandırma bacalarının yeniden inşaası

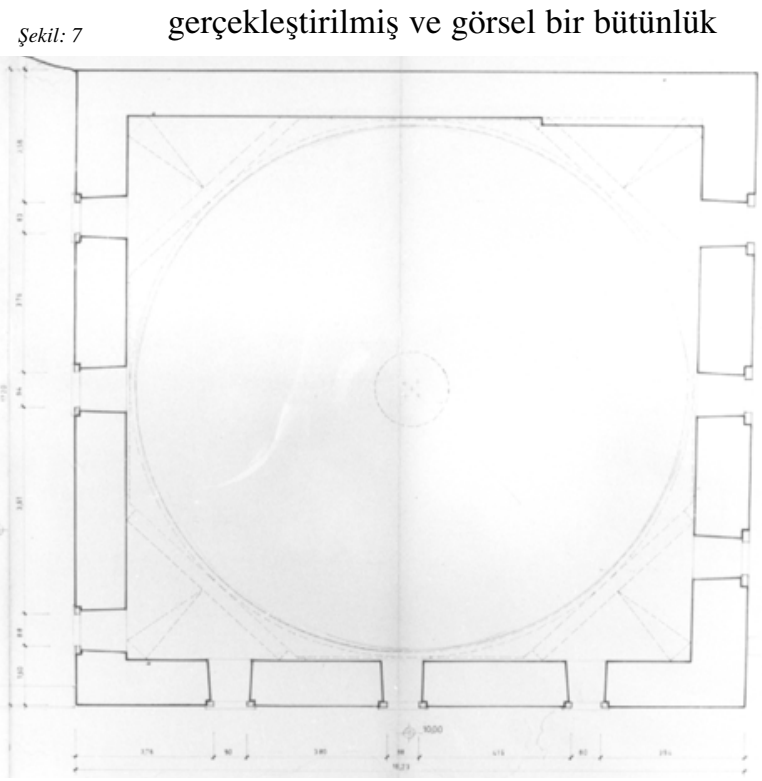

sağlanmıştır. Ancak buna karşılık taş duvar üzerindeki cümle kapısı saçak izlerinin ve ahşap cumbaların taş duvar dolgularının derz çalışmaları sırasında yok edilmesi olumsuz bulunmuştur.

Günümüzde mevcut kemer dizgesi içinde yeralan muhdes altıgen boşlukların yerinde daha önce mevcut ancak yüksek ısı nedeniyle dağıldıkları düşünülen otantik şebeke parçalarının yüzey araştırması yapılarak bulunması ve restitüe edilmesi gerekirdi. Koruma amaçlı onarım çalışmalarının özellikle büyük döküm binasında olmak üzere tamamlanmadığı anlaşılmaktadır. Günümüzde kuzey cephesinde yeralan pencere üst kemer aynaları ile birlikte tonozlu geçitlerde ve kapı bölümünde her- hangi bir sınırlayıcı eleman bulunmamaktadır. Bir başka deyişle bina dış tesirlere karşı savunmasız bırakılmıştır. İç mekânda ise yüzey araştırmalarına kısmen başlanmış olduğu ancak daha sonra terk edildiği anlaşılmaktadır. Küçük döküm binasında ise kubbe kasnağında yeralan ve muhdes olduğu öne sürülen pencerelerin geçmiş dönemlere ait her hangi bir belgesinin bulunmadan 


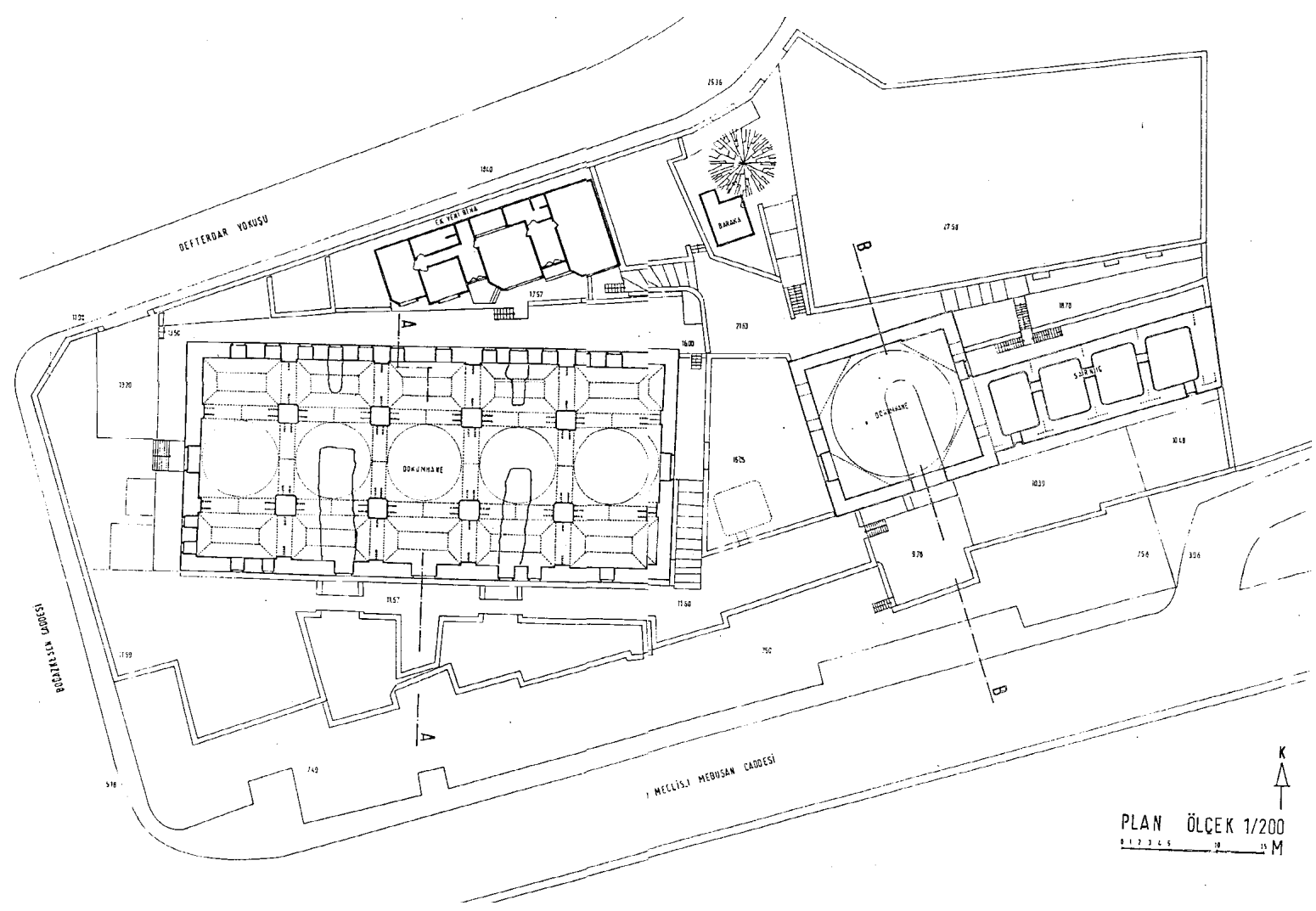

varsayıma dayanılarak iptal edilmesi bilimsel restorasyon kurallarına aykırı bulunmuştur. Söz konusu durumun, küçük döküm binasının güney cephesindeki pencere düzeni ile de bağlantılı olduğu ifade edilebilir.

Ülkemizde sıklıkla karşılaşılan, kamu binalarına ait onarımlarda ödenek yetersizliği konusu top döküm binalarının onarım çalışmaları sırasında da gündeme gelmiş ve onarım çalışmalarının uzun sürelere yayılmasına neden olmuştur. Ayrıca yapıların çevre şartlarının, yapısal ve mekânsal olanaklarının bilimsel yöntemlerle belirlenmeden ve gerçekçi olmayan işlevlerle donatılmak istenmeleri zaman içerisinde boş kalmalarına ve hızla yıpranmalarına zemin hazırlamıştır.

Top döküm binaları günümüzde Mimar
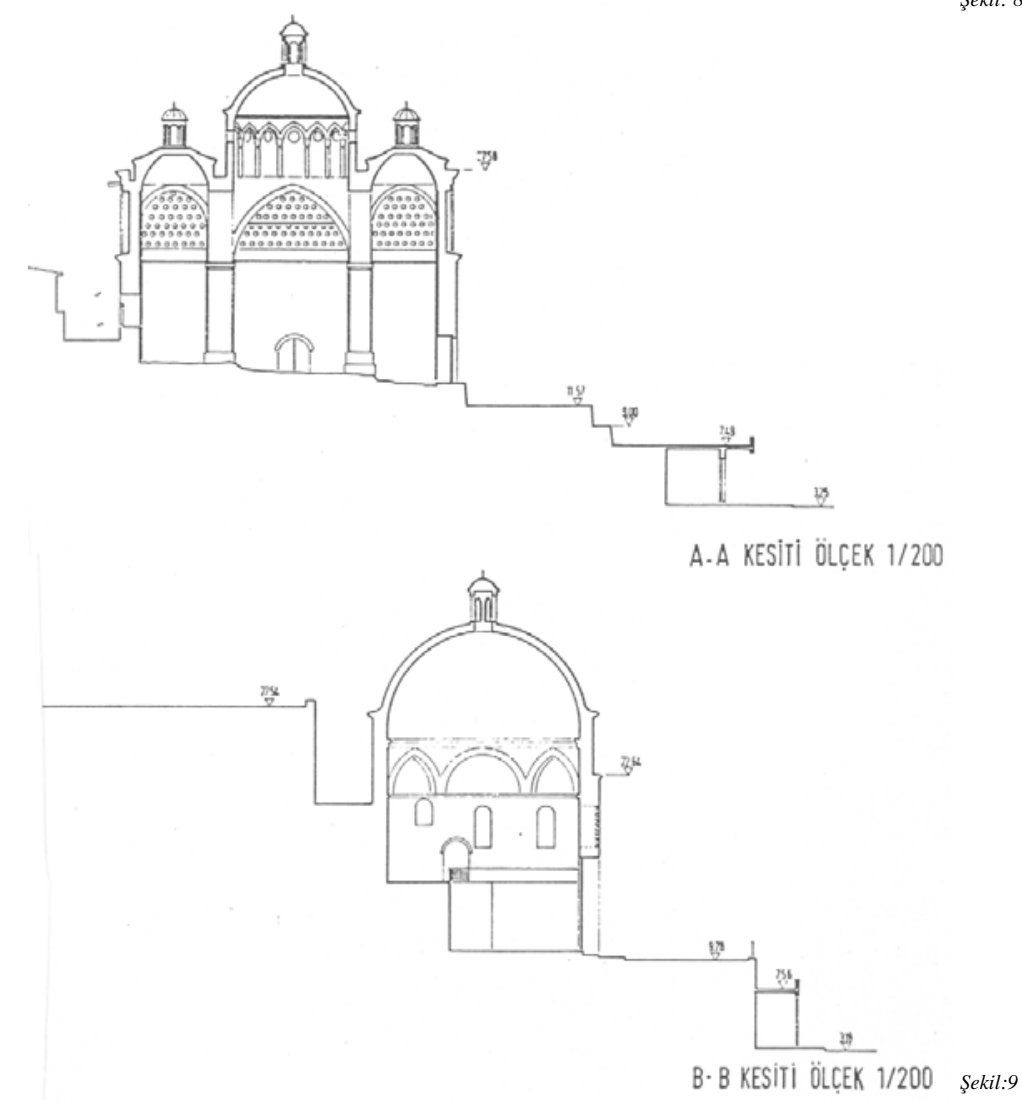


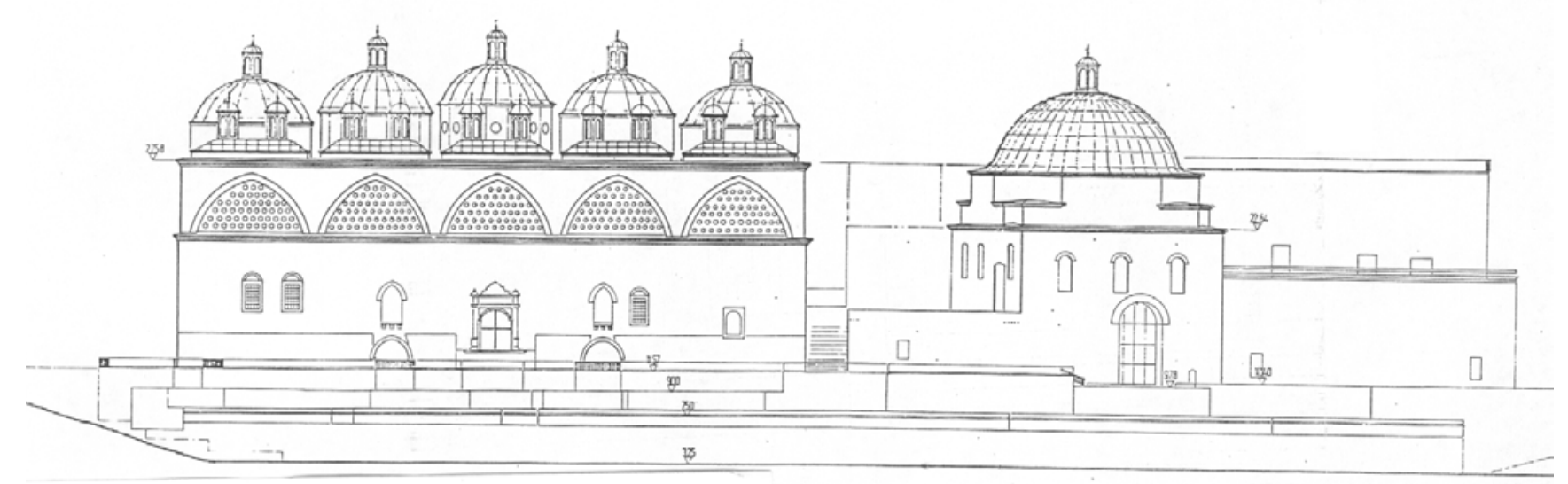

Şekil:10

Şekil: 8

Büyük ve küçük top döküm binalarının rölöve f̧izimleri, 1992. Bu f̧izimler MSÜ Mimarlık Fak. Restorasyon $A B D$ ögretim üye ve yardımciları tarafindan hazırlanmiştır. Zemin kat planları.

Şekil: 9

Büyük ve küsük top döküm binalarının rölöve f̧izimleri, 1992. Bu f̧izimler MSÜ Mimarlık Fak. Restorasyon $A B D$ ögretim üye ve yardimciları tarafindan hazırlanmıştır. Kesitler. Şekil: 10

Büyük ve küsük top döküm binalarının rölöve f̧izimleri, 1992. Bu f̧izimler MSÜ Mimarlık Fak. Restorasyon $A B D$ ögretim üye ve yardimciları tarafindan hazırlanmistir. Cepheler.

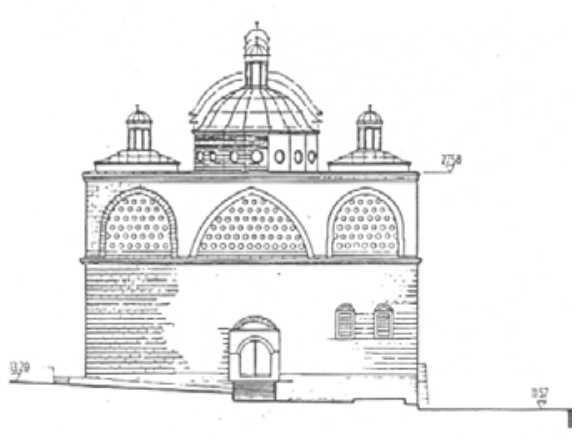

Top döküm binaları günümüzde Mimar Sinan Üniversitesi'nin kullanımındadır. Mimar Sinan Üniversitesi Mimarlık Fakültesi Restorasyon Anabilim Dalı'nca rölöve çalışmaları (Şekil 8,9,10) tamamlanan binaların işlevlendirilmeleri gündeme gelmiş ve buna yönelik proje çalışmalarına başlanmıştır. Büyük top döküm binasının işlevlendirilmesinde gözönünde bulundurulan husus, iç mekânın bölünmeden ve tek kerede algılanmasını sağlayacak bir çözümün üretilmesiydi. Ayrıca yüzey araştırmaları sonucu binanın zemininin arızalı olduğu tespit edilmiş ve bunun üzerine yüksekliği ayarlanabilen metal ayakların taşıdığ yüzer döşeme tasarlanmıştır. Özellikle iç mekân duvar yüzeylerinde olmak üzere, yüzey iyileştirici plastik onarımlar ve temizleme çalışmaları yapılmıştır.

Sözkonusu yapılar topluluğu günümüzde "Mimar Sinan Üniversitesi Kültür ve Sanat Merkezi" olarak işlevlendirilmiştir 1 


\section{KAYNAKÇA}

Arseven, C. E. 1989 Eski Galata ve Binaları, İstanbul. Arslan, N. 1992. Gravür ve Seyahatnamelerde İstanbul, İstanbul.

Can, C. 1993. İstanbul'da XIX. Yüzyll Batıl ve Levanten Mimarların Yapılart ve Koruma Sorunlart, (yayınlanmamıș Dr. Tezi) Yıldız Teknik Üniversitesi Fen Bil. Ens., İstanbul.

Cezar. M. 1996. Tophane, Mozaik, 2 / 13, 28 -38 Cezar, M. 1991. XIX. Yüzyll Beyoğlusu, İstanbul.

Cezar, M. 1963. Osmanlı Devrinde İstanbul' da Yangınlar ve Tabii Afetler, Türk Sanatı Araștırma ve Incelemeleri I, 327 -414.

Çoruhlu, T. 1996 Tophane, Ilgi, 86, 28 -35.

Eldem, S. H. 1979. Boğaziçi Antları, İstanbul.

Eralp, N. Emiroğlu, B. Çiçekçiler, E. Çürük, C. 1983. Askeri Müze, İstanbul.

Evliya Çelebi 1975. Seyahatname, İstanbul.

Gönen, E. 1999. Sur la rehabilitation et l'avenir de la Fonderie İmperial d'İstanbul (Tophane-i Amire), Anatolia Moderna VIII., Paris. 220236

Gönen, Güngören, E. 1995. Tophane -i Amire'nin Restorasyonu ve Geleceği Üzerine, YAPI, 167, $103-111$

Hobhouse, J. B. 1812. A Journey Through Albania and Other Provinces of Turkey in Europe and Asia to Constantinople During the Years 1809 and 1810, London

İncicyan, P. G. 1956. XVIII. Asırda İstanbul, ( çev. H. Andreasyan ), İstanbul.

Kömürcüyan, E. Ç. 1952. XVII. Asırda İstanbul, (çev. H. Andreasyan ), İstanbul.

Kritovulos, 1967. Tarih-i Sultan Mehmed Han-ı Sani, ( çev. Karolidi Efendi, haz. M. Gökmen), İstanbul.

Pakalın, M. Z. 1983. Tarih Deyimleri ve Terimleri Sözlüğü, İstanbul.

Raif Efendi. M. 1988. Osmanlı Imparatorluğunda Yeni Nizamların Cedveli, (çev. A. Terzioğlu -H. Hatemi ), İstanbul.

Şimşek, M. 1993. Batılılașma Sürecinde İstanbul' da II. Mahmud Dönemi İmar Faaliyetleri, (yayınlanmamış Dr. Tezi ), MSÜ, Sosyal Bil. Ens., İstanbul.

Terzioğlu, S. A. 1965. İshak Efendi, Ankara.

Ünsal, B. 1969. İstanbul'un İmarı ve Eski Eser Kaybı, Türk Sanatı Tarihi, 8 -61

Wiener, W. M. 1998. İstanbul Limanı, İstanbul.

\section{ŞEKIL KAYNAKLARI}

Arslan, N. 1992. Gravür ve Seyahatnamelerde İstanbul, İstanbul. Resim 3

Eyice, S. 1969. Galata ve Kulesi, İstanbul. Harita 1 Sahenk, H., 1996. Bir Zamanlar İstanbul, İstanbul. Resim 2

\section{ARŞIVLER}

-Atatürk Kütüphanesi Harita Arşivi

-İstanbul I Numaralı Kültür ve Tabiat Varlıklarını Koruma

Kurulu Arşivi

-İstanbul Rölöve ve Anıtlar Müdürlüğü Arşivi

-MSÜ Mimarlık Fakültesi Restorasyon Anabilim Dalı Arşivi 